WellBeing International

WBI Studies Repository

2019

\title{
The Land of Meat and Potatoes? Exploring Ireland's Vegan and Vegetarian Foodscape
}

Corey Lee Wrenn

University of Kent at Canterbury

Follow this and additional works at: https://www.wellbeingintlstudiesrepository.org/diecfaori

Part of the Animal Studies Commons, Other Anthropology Commons, and the Other Nutrition Commons

\section{Recommended Citation}

Wrenn, C. L. (2019). The Land of Meat and Potatoes? Exploring Ireland's Vegan and Vegetarian Foodscape. DOI: 10.31235/osf.io/t83yg

This material is brought to you for free and open access by WellBeing International. It has been accepted for inclusion by an authorized administrator of the WBI Studies Repository. For more information, please contact wbisr-info@wellbeingintl.org.

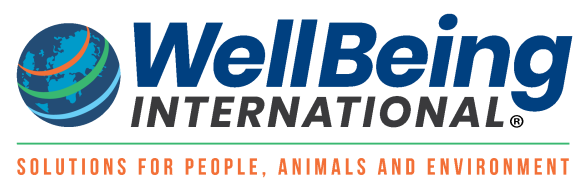


Corey Lee Wrenn, $\mathrm{PhD}$

Monmouth University

Department of Political Science and Sociology

Bey Hall 234

400 Cedar Avenue

West Long Branch, New Jersey

07764-1898

United States of America

Corey.wrenn@gmail.com

\section{The Land of Meat and Potatoes? Exploring Ireland's Vegan and Vegetarian Foodscape}

While it would not be accurate to suggest that Ireland is a hub of veganism or vegetarianism, too often it is written off as inherently unsympathetic to the ethics of plant-based eating and antispeciesist politics. While it is true that Irish culture is historically tied to speciesism and its economy is especially dependent upon "meat" and dairy production, Ireland's relationship with other animals is complex and sometimes forgiving. This essay seeks to bring shape to the Irish vegan ethic, one that can be traced along its history of animism, agrarianism, ascendency, adaptation, and activism. From its pagan roots to its legacy of vegetarianism, Ireland's history has been more receptive to Nonhuman Animal interests than might be currently understood. Its contributions to the modern Nonhuman Animal rights movement and developments in green agriculture must also be taken into account. More than a land of "meat" and potatoes, Ireland exists as a relevant, if overlooked, participant in Western vegan thought. 


\section{The Land of Meat and Potatoes? Exploring Ireland's Vegan and Vegetarian Foodscape}

In the introduction to a "green" travel guide to Ireland, author Rachelle Kaufman (2014) entertains an expected question from her foreign readers: "Is it true that Ireland is a land of meat and potatoes? Will I be able to find vegetarian food?" She responds carefully, noting that stereotypes of this kind obscure the true diversity of Irish cuisine. It is fair to say that vegan dining is not a commonality in the region, but Kaufman's guide asserts nonetheless that there are a few restaurants that would be very welcoming for vegans. As this example demonstrates, some guides are clearly picking up on the Irish vegan foodscape, but stereotypes of a monotonous and carnivorous Irish diet persist. A vegan guide to Ireland published by The Huffington Post insists that to be vegan in Ireland is "a challenge" that necessitates "research," "patience," and some degree of "compromise" that will have to accommodate nonvegan ingredients (Pure Adventures Travel, 2013).

Certainly, Ireland is similar to other Western countries in its heavy consumption of animal products. Government research finds that over $99 \%$ of the population consumes about 280 grams of dairy every day. Most of the Irish are eating "meat"1 on a daily basis as well, $80 \%$ of which are consuming pig's flesh, 71\% chicken's flesh, and 55\% cow's flesh (Kiely, 2001). Veganism is therefore statistically uncommon in Ireland, but it is not entirely absent. Between 5 and 10 percent of its population identifies as vegetarian (Irish Nutrition and Dietetic Institute, 2004; Leahy et al., 2010; Pichler \& Blackwell, 2007). These modern demographic descriptions may not be especially impressive, but the Irish foodscape is much more accommodating to vegan ethics than is commonly acknowledged. 
Ireland is certainly not a species-egalitarian society, but the role of Nonhuman Animals ${ }^{2}$ in the Irish way of life is unmistakable. Outnumbering human inhabitants, Irish cows sprawl across the countryside. Thousands of visitors board ferries hoping to spot whales off the coast of Cork or meet Fungi the free-living dolphin in Dingle's harbor. Celtic and early Christian history and folklore heavily feature Nonhuman Animals. In fact, for much of its history, Ireland's relationship with other animals was much less oppressive. As an animist culture, the early Irish acknowledged other animals almost as equals and as fellow inhabitants of the natural world. For that matter, the bulk of the traditional Irish diet has been plant-based until industrialization and modernization would make animal products cheaper, more accessible, and nearly unavoidable.

The introduction of Christianity and British colonization would ensure that relationships with other animals would become much more human supremacist. This influence also increased "meat" and dairy production in Ireland significantly. Specifically, the increased oppression of Nonhuman Animals was tightly linked with the increased oppression of the Irish under colonialism. The production of animal commodities swelled, but it did so primarily for the benefit of the British people and at the expense of the Irish peasantry. This oppressive relationship would famously push the Irish onto the potato, a vulnerability that would spell disaster when the crops would fail from disease.

Food memory in Ireland is compelling, and consumption patterns are highly political and deeply connected to the Irish identity. In addition to the legacy of famines in the $19^{\text {th }}$ century, for instance, Irish nationalists would employ hunger strikes during the Troubles of the latter half of the $20^{\text {th }}$ century to protest British imperialism (O'Malley, 1990). Nationalists of years earlier also politicized food, sometimes merging anti-speciesist vegetarianism with their efforts for Irish independence. Today, development in sustainable and regional food production has been 
prioritized as a means of achieving Irish self-sufficiency and competition in an international market beyond the harbors of Great Britain. This move has been especially harmful for Nonhuman Animals by institutionalizing their oppression, but this new green imagination in a global society has also supported the growth of Irish Nonhuman Animal advocacy.

Human/nonhuman relationships have heavily influenced the trajectory of Irish culture

and the Irish state, and this essay will explore the development of this relationship from Neolithic times to that of today. Specifically, this exploration will be grounded in the cultural, political, and economic developments of Ireland in the context of trans-species oppression. I will argue that this principle of intersectionality is foundational to Irish vegetarianism and veganism. The role of agrarianism, colonialism, and the modern capitalist concerns with marketplace competition and environmental protection will be examined as particularly influential in shaping the identities and experiences of both humans and nonhumans. The paper will therefore be divided into sections that will address ancient Ireland prior to its incorporation into the modern world system, Ireland under British colonization, and modern Ireland in the era of intensified globalization.

\section{Human-Nonhuman Relationships in Neolithic, Celtic, and Early Christian Ireland Ancient Ireland and Animism}

The relationship between Irish culture and flesh consumption has a fluctuating history. While it has been animal-based, it has not always been animal-intensive. Early Irish peoples relied on Nonhuman Animal flesh and milk as a major source of calories for thousands of years (Green, 1992; O'Kelly, 2001). Human communities of this region were uniquely lactose tolerant, a recent evolutionary adaptation to the limiting climate. Food systems of this time were certainly 
speciesist, but Neolithic human relationships with the natural world were profoundly meaningful and often sacred. This animism was particularly marked with the arrival of Celtic culture. Archaeologist Miranda Aldhouse-Green summarizes: "To the Celts, animals were special and central to all aspects of their world" (1992, p.4). For instance, the ancient Irish domesticated ravens and wrens for the purposes of augury and divination, a Druid craft that was particularly complex (Spence, 1999). Many species were also thought to have healing properties and were regularly included in traditional remedies. This association was strong with bees, for example, who were seen by the Celts as healers with strong connections to the afterlife. These associations would continue into later Irish folklore as manifested in the practices of fortunetelling with bees' wax candles, "telling the bees" (a ritual of announcing news to resident bee hives), and covering hives with black cloth when a human of the household expires (Chaomhánach, 2002). Irish folklore, too, regularly features human characters who can turn into nonhumans and back into humans (though, the reverse is less frequently fabled).

The predominance of nonhuman figures in ancient Irish epistemologies demonstrates some recognition that other animals enjoyed a social status much closer to that of humans. Irish historian Niall MacCoitir explains:

Animals are special to us because they are 'flesh and blood' creatures like we are, with recognizable drives and motivations. Crucially we can see that many animals are unique individuals, with personalities of their own, just like us. For this reason it is inevitable that we should project our own fears and desires on to them, and ascribe human motives and characteristics to them (MacCoitir, 2010, p.236).

This elevated status, however, would not protect them from human oppression, as Nonhuman Animals were nevertheless subject to systemic violence to suit human interests. The inability of 
Nonhuman Animals to become human in Irish myths and stories indicates a recognition of human supremacy despite the high regard nonhumans were granted. Indeed, these tales often feature human-to-nonhuman shape-shifting as a form of punishment or as a means of serving the interests of humans in some way (Green, 1992). The animist culture, in other words, is still human-centric. Because violence against Nonhuman Animals necessitates significant psychological distancing, it is speculated that mythologizing them allows humans to connect to other species in a way that also normalizes speciesism ideologically (Poloczek, 2015).

\section{Relationships with Free-Living Animals}

Humans treated various species differently based on their socially constructed purpose in Irish society. Domesticated animals were most often consumed as food, but free-living animals were less frequently so. More often, "hunting" was engaged for ritual purposes, attaining skins, to reassert male and human supremacy, or for the entertainment of the nobility. Archaeological evidence suggests that Iron Age communities before the arrival of the Celts were even less interested in "hunting." Nonetheless, free-living species like wolves, brown bears, lynxes "wild" boars and cats, red deers, and red squirrels would eventually be driven to near or complete extinction, ${ }^{3}$ if not from "hunting" for human consumption or to reduce competition, then by human encroachment and habitat destruction, much of which was linked with the keeping of domesticated animals (Yalden, 1999). ${ }^{4}$ The killing of free-living animals sometimes required the assistance of oppressed domesticated animals such as horses, hawks, and dogs. For commoners who could not afford these nonhuman accomplices, snares, traps, and spears were popular killing instruments. 
The exaltation of human relationships with free-living animals and the symbolic importance of the "hunt" surfaces regularly in Irish mythology. A number of these tales, notably that of Fionn mac Cumhaill, feature those such as stags and boars who act as emissaries to the supernatural. These tales served to normalize the role of domination in the human social order by figuratively subordinating vulnerable humans and other animals, and also by exploiting the admired qualities of other animals to achieve and maintain hierarchies of power. In other words, Nonhuman Animals would become the vessels of human efforts for social control. Nonhuman Animal imagery would also prominently appear in war mythology and surviving artifacts of Celtic battle accoutrements. This imagery could be utilized to instill fear, or to evoke prediction and protection in combat. Liath Macha (the Grey of Macha), a chariot horse from the tale of Cú Chulainn, was for instance thought to possess clairvoyance, as were the "Badbh Catha," or battlefield ravens who could take human form (Sjoestedt, 2000). ${ }^{5}$

\section{Relationships with Domesticated Animals}

Domesticated animals such as horses, sheeps, pigs, oxen, and cows represented wealth, and this economic function would aggravate their vulnerability to human violence and exploitation. Most of these species are thought to have been introduced to Ireland with human settlers (van Wijngaarden-Bakker, 1974). As prized possessions, they are heavily referenced in historical narratives, myths, pottery and cooking utensils, jewelry, and art (Green, 1992; Mac Coitir, 2010). Animals were also given as tribute to early clan leaders in pre-colonial Ireland, as is fabled of the famous Brian Boru (otherwise known as Brian of the Cattle Tributes) (Newman, 2011). As is the case in other human societies, the status of other animals hinged more on their socially constructed worth than their biological predispositions. Ancient Irish culture created 
taboos against the exploitation of some animals, while it ensured the mass slaughter of others. Of those animals oppressed by ancient Irish peoples, killing seems to have been committed by throat-cutting and corpses were generally cooked in large cauldrons. Their remaining body parts would be formed into clothing, drinking and utensils, tools, and other items of use.

Despite the prominence of violence against Nonhuman Animals in Irish culture, the Irish diet prior to British colonization was rather low on "meat." Cows were exploited primarily for dairy production and ploughing and sheeps for their hair and milk. It was primarily older, unproductive animals who would be killed to procure their flesh (Green, 1992; Hickey, 2015; Lucas, 1960) or male young who could not produce prized breastmilk. Those that were killed for this purpose were largely reserved for aristocrats (Cowan and Sexton, 1997). Indeed, dairying easily reaches back to Neolithic times, as pottery from the era has tested positive for milk lipids. Landscape archaeology indicates an economy that relied heavily on the oppression of milking cows and their children (Caulfield, 2013).

Of those animals that were consumed, pigs appear to be the most victimized. The Celts regularly killed free-living and domesticated pigs, sometimes using them in harvesting rituals or sacrifice (Simoons, 1994). In later years, monasteries systematically exploited pigs and many Irish saints began as pig "herders." Pre-Christian Irish peoples ate horse flesh as well, and Roman propagandists reported Celtic rituals that involved raping a mare before killing and eating her. Horses were also heavily exploited for plowing, transportation, and war.

Although exploitation varied by species, most nonhuman communities were vulnerable in one way or another. Lough Gur in County Limerick, a popular living and worshiping site for Neolithic peoples where Ireland's oldest and largest stone circle is located, was found to contain the bones of a wide variety of both domesticated and undomesticated animals (Grogan et al., 
1987; Ó Ríordáin \& MacDermott, 1949), as was Newgrange in County Meath (van

Wijngaarden-Bakker, 1974). Archeological evidence also supports that sea inhabitants were a part of the early Irish diet, as might be expected for a human-dominated island with considerable coastline, marshes, and rivers (Lucas, 1960).

As has been eluded to, the precious nature of domesticated animals would account for their regular use in ritual killings. Dogs, cats, sheeps, cows, pigs, and other animals (or their body parts) were regularly deposited in ritual pits, grain stores, and graves. Domesticated animals were also slaughtered and consumed in large numbers for ritual feasting. There are some contemporary reports of Celtic sacrifices which note the burning of both human and nonhuman animals in wicker structures. The sacred role that the consumption of Nonhuman Animals played in early Irish life surfaces often in lore and folk custom. Some myths depict doomed pigs as regenerative, remaining alive after being butchered to provide never ending sustenance (Green, 1992). For some animals, these myths would become protective, particularly by way of totemism. The Eurasian crane, now extinct in Ireland, for example, was believed to have mystic qualities and was associated with the divine. This is thought to explain a traditional Irish taboo on their consumption (O'Toole \& O'Flahert, 2011).

\section{Early Irish Diet}

Despite these decidedly speciesist practices, it would probably be most accurate to describe ancient Ireland as agrarian, with "meat" consumption reserved for the wealthy. The early Irish diet was cereal-based and heavy in barley, flax, and oats (Monk, 2013; Salaman, 1985), and many homes had small milling stones or querns. These grains (and sometimes wheat) were regularly made into bread or porridge (Lucas, 1960). In Celtic legends, successful 
kingdoms were marked by bountiful fruit and vegetable harvest, indicating the cultural importance of plant foods (Sexton, 1995). Dairy (or what would later be referred to as "white meat" or "bàn bídh") was also a staple that was drunk both fresh and sour. It was also eaten as butter on bread, milk in porridge, cheese, and so on. Forgotten stores and ritual deposits of butter are still found in naturally preserving bogs today (Earwood, 1997). Seaweed, wild vegetation, nuts, crab apples, berries, and fungi were gathered and sometimes managed, though fruit and vegetables were not widely cultivated until the late Middle Ages (Hickey, 2015; Lucas, 1960; Monk, 2013). Beans, peas, cabbage, and innovative horticultural techniques appear to have been introduced with the establishment of monasteries, but also through Norman development in the area (Sexton, 2013).

Analyses of Ireland's famous bog mummies often show that the victim's last meal was vegan or vegetarian. This could indicate the time of death was in warmer seasons when Nonhuman Animals were not usually slaughtered, or it could be that the plant-based meal held some sort of ritual significance (most bog bodies are victims of sacrifice) (Ahlstrom, 2011; Lobell \& Patel, 2010). Indeed, a number of Irish plants were known to have medicinal properties or were thought to have spiritual or magical significance (Mac Coitir, 2006). This relationship would continue into early Christian and even modern times. For instance, cabbages were used in fortunetelling, specifically for the prediction of future marital partners (Sexton, 1995). Monasteries practiced herbalism and native plants such as shamrock or wood sorrel (valued by the Druids for its healing and strengthening powers) became embedded within Christian theology (MacConnell, 2016).

The Impact of Christianity on Irish Human-Nonhuman Relationships 
Ireland may have avoided colonization by the Romans, but Irish traders and marauders did interact with Roman Britain, and missionaries were common beginning in the $5^{\text {th }}$ century. Inevitably, Christianity would come to transform early medieval Ireland. For one, Roman influence and increased nutrition made available by agricultural advancements would increase the size, and, presumably, the health of domesticated Nonhuman Animal species. Despite these improved "husbandry" practices, most domesticated animals were of course still destined for slaughter. If anything, new Christian ideologies would worsen Nonhuman Animals' welfare overall. While animist Celts respected other animals as sacred, Roman thought would shift the Irish relationship with other animals to one of anthropocentrism whereby Nonhuman Animals would be further subordinated and viewed as divinely-sanctioned resources (Green, 1992).

The transition to Christianity was not abrupt, however, and involved considerable intermingling, borrowing, and accommodation. This surfaces in trans-species mythology that narrates the cultural shifts of the era. The tale of the Children of Lir, for instance, merged traditional Irish animism with emerging Christian values. In this story, a jealous mother transforms her stepchildren into swans who could only be freed after 900 years by the ringing bells of Christendom. There is also the tale of "Mad Sweeney," a pagan king banished to an avian-like existence for attacking a saint. After a long existence exiled to treetops in woodlands and traveling by flight as a bird would, he would eventually find refuge in a monastery (Bergholm, 2005; Sailer, 1998).

The Catholic denomination that would come to characterize Ireland is not especially dedicated to anti-speciesism. For example, Saint Patrick is famously fabled to have driven snakes from the island (snakes were likely a metaphorical representative of "sinful" paganism) (Owen, 2014). Likewise, Saint Patrick's Day was the traditional time for the killing of pigs for human 
consumption in Ireland (Cowan and Sexton, 1997) (pigs' heads in particular were a favored dish) (Sexton, 1995), and Saint Stephen's Day historically involved the killing of wrens. ${ }^{6}$ Saint Modomnoc is thought to have doomed generations of bees to suffering when he supposedly brought bees and their honey production to Ireland, and bees' wax and honey became a religious staple in Christian ceremonies (Crónín, 1995) (Saint Gobnait, too, is heavily associated with bees and their ability to heal humans) (Chaomhánach, 2002). There is also Saint Martin's Eve, featuring a sacrificial ritual that necessitated the killing of a sheep, chicken, or goose, whose freshly spilling blood was sprinkled in the corners of homes and applied to doorposts (Morris, 1939).

Nonetheless, some concern for other animals does emerge from the new faith. By the $9^{\text {th }}$ century, the church was penalizing the pagan practice of consuming horse flesh (Simoons, 1994). To this day, the Catholic faith encourages believers to abstain from animal flesh on Fridays, particularly during Lent. Although fishes would not be spared by the observance, carrageen moss was traditionally gathered on Good Friday in preparation for mostly "meat"-free fare (Cowan and Sexton, 1997). There is also the Feast Day of Saint Francis of Assisi that may include ecumenical service for Nonhuman Animals. A number of early Christian saints of Ireland, in fact, were believed to harbor a strong connection to Nonhuman Animals and nature (Green, 1992). The Book of Kells liberally utilizes Nonhuman Animal characters and representations to tell the story of Christianity (Casey \& Ryan, 2015; Mussetter, 1977). Neither has this tradition has been lost to modern Catholicism. Formed in 1929, the Catholic Concern for the Animals (CCA) (formerly the Catholic Study Circle for Animal Welfare) seeks to increase awareness of anti-speciesism and vegetarianism in the religion's ideologies and rituals. ${ }^{7}$ Though Londonbased, it has been quite active in Ireland as well. ${ }^{8}$ 
The adoption of Christianity would significantly alter the Irish relationship with other animals, but this shift was at least congruent with preexisting Irish values. The role of colonialism and Ireland's introduction into the modern world system would arguably have a more dramatic impact on Ireland's nonhumans. Under British rule, Ireland's meadows, farms, and pastures were increasingly placed under the jurisdiction of absentee British landlords who were especially interested in producing "beef" for export. The indigenous Irish population would soon find itself without political representation, land rights, or food security. This meant that "meat" would become an item of luxury and privilege. In a time of increased agricultural sophistication, animal products would ironically become less accessible to the overwhelming majority of Ireland's populace.

\section{Post-1500 Tenant Farming, Famine, and British Colonialism}

The Irish relationship with food is one that remains somewhat tainted by cultural memories of oppression, poverty, and hunger. A modern Irish vegan ethic must therefore be cognizant of the political history of food and eating, particularly in the context of colonialism. In addition to early tensions with Viking invaders in the Dark Ages, Ireland was also occupied by the Normans in the $12^{\text {th }}$ century. Following Norman colonization, many native Irish lost control over their land and would thereafter become tenants or otherwise destitute. While this early contention is certainly relevant to Ireland's trajectory, historians generally divide Irish history at the point of earnest English colonization in the 1500s following the monarchy's split from the Catholic Church and its commitment to creating a Protestant kingdom inclusive of Ireland. This is also a time when European trade was greatly expanding into what would become a world system (Halley, 2012). England's renewed interest in subduing the Irish in tandem with Ireland's 
now vulnerable position in the periphery of a new global economy would significantly transform traditional ways of life. English taxation over the Irish was extreme, technological advancements in agriculture would be stunted, ${ }^{9}$ and the population grew very rapidly with the support of the potato (Hickey, 2015). As a result of this troubled incorporation into the British system, the majority of the Irish population experienced impoverishment well into the $19^{\text {th }}$ century (Salaman, 1985).

\section{Changing Diets under Imperialism}

Most of the Irish lacked the same rights and privileges afforded to the people of England in regard to food accessibility. For instance, the killing of free-living animals was forbidden for Irish persons under English rule. In fact, colonialism ensured that many of the Irish poor ate plant-based diets as a result of their class position (Cotter, 1996), while the English population's diet would become much more varied (Clarkson \& Crawford, 2001). Pre-Famine workhouse records show that meals consisted primarily of potatoes, supplemented with cow's milk and the occasional fish flesh. However cows' milk would become too precious for the peasantry to afford as industrialization increased demand in larger cities and inflated prices (Wiley, 2011). To supplement their meager diet, cows were regularly bled to access a renewable source of protein (Clarkson \& Crawford, 2001) (though the practice dates back at least to the Middle Ages) (Cowan and Sexton, 1997; Sexton, 1995), and blood sausages and puddings remain moderately popular in Irish cuisine today. Animal products were considered precious, and generally reserved for special occasions such as holidays, weddings, and to a lesser extent wakes (Sexton, 2002), though the pre-Famine proliferation of potatoes meant that many more families could afford to keep pigs for eventual consumption, as pigs could be cheaply fed on potatoes as well (Sexton, 
1995). "Meat" and dairy production was actually rather lively in the $17^{\text {th }}, 18^{\text {th }}$, and $19^{\text {th }}$ centuries, but most of it would be exported or otherwise consumed by wealthier classes and landowners in Ireland. The more perishable organs and entrails of nonhuman victims were unsuitable for export and subsequently expanded in Irish diets, particularly so for the lower classes (Sexton, 1995). Likewise, the Irish butter industry dominated agricultural export for some time, most of which, again, went to Britain (Donnelly, 1971). This polarization between the classes in diet continued into the $19^{\text {th }}$ century, with about $90 \%$ of the Irish population eventually coming to depend singularly on the potato (Salaman, 1985). With a growing population and less available land (due to both British imperialism and the shift away from communal inheritance practices in Ireland), potatoes were affordable and adaptable.

\section{The Double-Edged Potato}

In the context of political powerlessness and landlessness under British exploitation, this singular dependency on the potato would prove disastrous. The very same conditions that helped potatoes to thrive in the wet and cool climate of Ireland would also welcome blight. By this time, traditional methods of food production had been largely lost, long since subsumed by potato production (Lucas, 1960). A large peasant population was subsisting on small landholdings with severe restrictions on what tenants could grow. This was compounded by the introduction of British Corn Laws that would restrict Irish trade to the benefit of Britain and balloon grain prices for Ireland. As a result, potatoes had become essential for sustaining the poor. This extreme reliance on the potato aggravated Ireland's vulnerability. Following the blight, a quarter of a million would be evicted from their homes, and over a million would perish from hunger or disease. Many more would leave the country if they had the means to do so. A considerable 
number of these refugees would not survive the journey on overcrowded ships. The Great Famine of the 1840s would have a lasting impact on the country's population, reducing it from 8.2 million to 6.6 million. In the half century following this decline, the population would further reduce to 4.6 million, mainly due to emigration and changes in family structure (Public Record Office of Northern Ireland, n.d.). ${ }^{10}$

\section{The Nature of Relief Efforts}

Acknowledgement and assistance from Britain was minimal and inadequate. Indeed, English reports from the time minimized the extent of the damage or even suggested that Irish diets were nutritionally sufficient (Clarkson \& Crawford, 2001). A Malthusian philosophy that put faith in laissez-faire market ideology was prevalent as well. This Darwinian reasoning understood poverty and overpopulation to be part of an evolutionary process of eradicating weaker economic participants in society, meaning that the Irish themselves were sometimes blamed for the disaster. Meanwhile, British landowners saw the crisis as an opportunity to exploit Irish powerlessness and intensified exploitative agricultural practices to dramatically increase "meat" production (Ross, 1987). Historian Tim Pat Coogan (2013) goes so far as to describe the event as an act of deliberate genocide.

Here, the vegan ethic, which is critical of state economic manipulations that entrench speciesism and ensure systemic suffering, becomes especially relevant for explaining this tragedy. The vegan ethic also surfaces to some extent in resistance. Famine survival strategies and relief efforts were largely plant-based. Parsley, nettles, sorrel, charlock, leeks, and other native herbs and wild-growing plants were gathered and eaten. Cabbage could often be relied upon as an emergency foodstuff, especially valuable in the mid-summer months when other 
crops could not yet be harvested (Cowan and Sexton, 1997). Indeed, cabbage was so heavily consumed in at was known as Iúil an cabáiste (July of the Cabbage) (today more commonly remembered as "Hungry July"), the skin of the populace was said to be tinted green (Kinmonth, 2006). Corn and rice were imported with mixed success. Many of the foods imported for relief were foreign to the Irish poor, and improper cooking due to ignorance or lack of cooking utensils and fuel aggravated their condition (Hatton, 1993). Some charities offered assistance that was vegetarian. The Quakers provided a number of grains and staple goods in addition to monetary relief. ${ }^{11}$ Oatmeal in particular would enjoy a resurgence at this time (Cowan and Sexton, 1997). Asenath Nicholson, an American philanthropist who worked with Irish immigrants in the United States also traveled to Ireland during famine to report on conditions, rally for relief, and offer assistance. She was a dietary reformer who published on plant-based living and operated a vegetarian boardinghouse in the slums of New York City (Murphy, 2015). ${ }^{12}$ She, too, offered soup and other vegetarian forms of sustenance to the suffering survivors.

The role that plants played in assistance is not to negate the suffering of Nonhuman Animals. In times of starvation and natural disaster, Nonhuman Animals tend to become especially vulnerable in human-centric spaces. They are often the last to eat and likely to be eaten themselves. For instance, there are contemporary observations of starving dogs who had resorted to consuming the corpses of human victims, while these dogs were themselves targeted by starving humans (Hatton, 1993). "Livestock" rustling increased tenfold during this time as well (BBC, 2016), and presumably these animals met lethal fates. Communities of sea dwellers, such as fishes and cockles, were hard hit as well. Eels, at least, would be spared in future generations, as their consumption had been stigmatized by the poverty and desperation associated with the practice during famine times (Cowan and Sexton, 1997). 


\section{The Legacy of Famine}

Additional potato blights would attack crops throughout the remainder of the century, but the Irish peasantry had greater ability to improve their land following the 1870 Landlord and Tenant Act. They also enjoyed higher wages and had access to a greater variety of food stuffs, thereby staving off famine conditions of earlier magnitude (Salaman, 1985). Recall that Ireland had been producing ample foodstuffs during famine times as well, but political conditions meant that food would be exported while the exploited Irish poor could generally only afford access to the potato. Even in a time of plenty, the failure of the potato had ensured starvation. Indeed, for those who could afford it, foods were varied and plentiful enough (Walsh, 2016), and, for this reason, it may be inappropriate to term the event a "famine".

Though Poor Law Unions attempted to discourage Ireland's reliance on the potato with the promotion of turnips and cereals (Friel \& Nolan, 1996), potatoes would remain a staple of the Irish diet. Today, over $99 \%$ of the population consume an average of 225 grams each day (the equivalent of one large potato) (Kiely, 2001). The relationship between the Irish and the potato is, however, notably transformed. Historian Redcliffe Salaman observes, "[...] the potato is eaten because it is liked, not because it is necessary. [...] The potato is happily, no longer the arbiter between a bare sufficiency and starvation" (1985, p.331).

The post-Famine diet appears to have become increasingly plant-based as Ireland continued to export expensive animal products (Clarkson \& Crawford, 2001). Cheese-making declined significantly, and few could afford to eat butter. Meanwhile, the increasing availability of processed foods and sugar would have a deleterious effect on the population (Friel \& Nolan, 
1996). Although Ireland was seeing some improvements in its agriculture, Britain's hold over Irish production and ability to consume was still quite strong. There were, however, pockets of Irish mobilization seeking to attain some degree of self-sufficiency and self-governing. This uneasy relationship in the shadow of The Great Famine would ultimately lead to a renewed push for independence and the eventual formation of a republic.

\section{Intersecting Oppressions}

Britain's oppression of the Irish was intimately tied to the oppression of other animals. Indeed, one sociologist suggests that the British colonial system is built on violence against domesticated animals, which, in turn, also requires systemic violence against the Irish (Nibert 2013). ${ }^{13}$ The exploitation of vulnerable peripheries such as Ireland provided the wealth and resources necessary to increase "meat" and dairy production. ${ }^{14}$ One source reports that, in 1880 , over half of the island and two-thirds of its wealth were tied up in the cattle industry alone (Ross, 1987). Ireland had essentially become an outsourced cattle farm, providing the English with luxurious animal products while millions of Irish were food insecure, undernourished, or forced to emigrate. The suffering of the Irish people, therefore, cannot be fully appreciated or understood without also acknowledging the suffering of the Irish cows, pigs, sheeps, fishes, and other animals and the oppressive ideologies that accommodated it.

As far back as the $17^{\text {th }}$ century, as tensions between Protestants and Catholics grew more perilous, portrayals of the Irish as wild, untamable, and barbaric helped to justify English colonization as a sort of philanthropic effort. They also shaped the English identity of superiority in the process (Laurence, 1988; Noonan, 1998; O’Connor, 2010). The Irish were described as savage, "wolf-like," and lacking pedigree. They were also animalized by the English based on 
their tendency to live and work closely with sheeps and cows. Irish women in particular were likened to "livestock" in their supposed ability to give birth frequently and painlessly without need for assistance or recovery. Likewise, Irish women were transported in great numbers to Australia as "breeding stock" by the English government in its attempt to control crime and instill order in Ireland while strengthening its foothold in Oceania (BBC, 2016).

The entangled subordination of Irish peoples and Nonhuman Animals is further evidenced in English $19^{\text {th }}$ and early $20^{\text {th }}$ century depictions of "Paddy" which animalized the Irish as ape-like in appearance and behavior as a means to subvert Ireland's post-Famine nationalist organizing (Curtis, 1997). So, too, were the Irish represented by pigs or associated with pigs based on their shared agricultural connection and supposed filthiness (O'Connor, 2010). The Irish were likened to dogs as well, a consequence of their perceived propensity for disease and supposed link to rabies. This stereotype derived from the English valuation of purity in morals, class, and race, but also from their fear of foreign invasion (Pemberton \& Worboys, 2007) (America also attributed disease stigma to animalized Irish immigrants for similar reasons) (Kraut, 1994). Much of this association stemmed from the English desire to civilize and control the presence of "mongrels" in the empire, an intent that endangered humans and dogs alike. ${ }^{15}$

In fact, a number of practices associated with the lower Irish classes would be scrutinized or judged more harshly than that of the English ascendency (Collins, 2015). Imperialist Britain often romanticized noble British traditions like fox and stag "hunting” as a symbol of Britain's supremacy, while it simultaneously presented cock fighting and other customs associated with the lower classes and colonies as evidence to their need for British rule (Deckha, 2013). Even in medieval Ireland, Anglo-Normans and church leaders who sought to control a conquered Ireland and reform its churches would propagandize their ill treatment of other animals to demonstrate 
Irish barbarism (Connolly, 2011) (recall, for example, the gruesome stories of Nonhuman Animal sacrifice discussed previously). Beyond pagan practices, the Irish were also thought negligent in minding their cattle, who reportedly grazed to the point of exploding (Freeman, 2001). Ireland's cruelty to Nonhuman Animals and improper attention to their welfare thus became a justification for British sovereignty there.

Consumption patterns, too, helped frame this class divide. The Irish were thought brutish in their consumption of blood and raw flesh on one hand (Fitzpatrick, 2004), ${ }^{16}$ while presumed weakened by the scant amount of "meat" in their diet on the other (Noonan, 1998). Furthermore, the consumption of Irish vegetables was stigmatized in England, perhaps because eating inferior or "tainted" foods from a stereotyped region was thought to undermine English cultural superiority.

\section{The Modern Irish Food System}

Though times of mass hunger and deprivation are associated with times gone past, historians note that the poignant memory of The Great Famine would shape Irish culinary imagination (or lack thereof) well into the $20^{\text {th }}$ century. It would not be until relatively recently that Ireland's foodscape would begin to witness any significant change, thanks in part to the influx of economic security and prosperity. A food consumption survey completed in the year 2000 suggests that "increasing affluence and changing lifestyles" had resulted in a dramatic change in Irish dietary habits (Kiely, 2001). Certainly, the industrialization of Nonhuman Animal agriculture was partly responsible, with Ireland seeing a 74\% increase in "meat" consumption since the 1930s (and a tripling of fish consumption) (Friel \& Nolan, 1996). As recently as 2003, Ireland ranked $10^{\text {th }}$ in global consumption of "meat" and also ranked quite high in its 
consumption of dairy (Speedy, 2003). As with other developed nations in the West, Nonhuman Animals killed for human consumption are primarily chickens, cattle, and pigs. In $2011,30 \mathrm{~kg}$ of pig's flesh, $25 \mathrm{~kg}$ of chicken flesh, and $20 \mathrm{~kg}$ of cow flesh was consumed per capita (Central Statistics Office, 2012).

Ireland's reliance on animal products runs deeper than dietary preference, of course, as it intimately shapes the island's economic development. At the turn of the $20^{\text {th }}$ century, agricultural production remained the primary Irish industry. Relationships between tenants and landowners had improved, but international competition was straining Irish farmers and impoverishing rural dwellers. The resulting co-operatives movement and the Irish Agricultural Organization Society formed to coordinate it would create a sense of self-reliance, granting Ireland some leverage in the market. Unfortunately for cows, it also increased dairy production considerably (King \& Kennedy, 1994).

The Irish food industry experienced significant restructuring in the mid-1980s, and animal agriculture would see even greater growth thanks in part to rationalization, concentration, and product diversification (Harte, 1997). Although entry into the European Union would expand Ireland's previously agriculturally dominant economy into other areas of production such as technology services and pharmaceuticals, "meat" and dairy remains a high priority business (Friel \& Nolan, 1996; McDonagh \& Commins, 1999; Tovey, 1991). Indeed, it dominates the modern Irish economy much as it did under British rule, accounting for $69 \%$ of food and drink exports. In 2014, the country conveyed approximately 6.6 billion euros worth of living and nonliving Nonhuman Animals and their excrements (Bord Bia, 2015). The agri-food sector has become the island's leading indigenous industry, with dairy and "seafood" demonstrating the strongest growth (Bord Bia, 2015). While only responsible for 1\% of the global dairy supply, 
there are 18,000 dairy farmers and about a million dairy cows farmed in Ireland with Irish dairy exports rising by as much as $30 \%$ in some recipient countries (Bord Bia, 2015). With 7,500 kilometers of coastline, Ireland's sizable "seafood" sector is strong. The value of aquatic exports has risen by $70 \%$ since 2009 , and 11,000 are currently employed in the industry (Bord Bia, 2015). In addition to the 18,000 dairy farmers and 11,000 "seafood" workers, there are also over 10,000 people working in the Irish "meat" industry (Food and Drink Industry Ireland, 2015). At least 39,000 of Ireland's population of 4.6 million are directly employed in businesses of speciesism. Incidentally, the modernization of the Irish economy has also ensured that many nonhuman species are subjected to vivisection, likely a consequence of modern Ireland's robust pharmaceutical industry. Despite the European Union's intention to phase out Nonhuman Animal testing, Ireland was responsible for the exploitation of about a quarter of a million animal subjects in 2014 (D’Arcy, 2015). Ireland has also been slow to monitor the trade in exotic species. Following the economic collapse in the early 2000s, a large number of snakes (purchased as status symbols on an island where snakes are not native) were abandoned in large numbers (Chozick 2013).

\section{Loving Ireland, Buying Local}

As a semi-periphery nation in the wake of British imperialism, Ireland remains heavily agricultural and reliant on tourism with high unemployment and high emigration. Economic policies in Ireland of the early $20^{\text {th }}$ century were heavily protectionist, discouraging foreign competition (Baker, 1990; Tovey and Share, 2000). Today's global Ireland celebrates and supports Irish farmers while also capitalizing on global markets. The response has been a more 
or less positive and profitable one, though the increasing role transnational corporations play in the Irish economy may be cause for concern and benefits of growth are unevenly distributed.

One notable development in Ireland's animal-based economy as it modernized and eventually joined the European Union in 1973 is its concerted interest in sustainable food systems (Tovey, 2006). A number of events and arrangements have encouraged the resurgence in local, sustainable production and consumption including the collapse of the Celtic Tiger and Ireland's loss of global competitiveness; several devastating outbreaks of disease borne from animal agriculture; ${ }^{17}$ and the 1994 introduction of Ireland's Rural Environmental Protection Scheme in tandem with the EU's Common Agricultural Policy (CAP). Rising incomes, increased vacationing, greater media attention to gastronomic cultures (McDonagh \& Commins, 1999), and the efforts of Irish celebrity chefs Myrtle and Darina Allen (Sage, 2003) have further piqued Ireland's attention to locally-produced food stuffs. Perhaps, also, the violent legacy of The Great Famine continues to undergird Ireland's concerns with self-sufficiency in food production (it certainly informed the politics of Irish nationalism in the $19^{\text {th }}$ and $20^{\text {th }}$ centuries) (Kinealy, 2001).

Buying Irish has become an important political action that resists the "colonization" of Irish economies by international corporations and imported goods and energy. It is a means of reskilling Irish farmers and supporting rural communities (Tovey, 1997). In addition to ensuring food security within its borders, these food initiatives are also providing Ireland an international presence and allowing for greater political and economic cooperation. As one of several examples, Ireland currently participates with the European Union in the Transatlantic Ocean Research Alliance with the United States and Canada to monitor and manage ocean "resources" as part of its blue economy initiative (Heffernan, 2014). Subsequently, Tovey and Share (2000) insist that Ireland's vigorous commitment to agriculture represents not its late modernization or 
"backwardness," but rather its forward thinking. This "agrarianization" is not an indication of slow development, but is instead a marker of achievement.

Beyond self-sufficiency, these new food systems are a means of locating a sense of trust and confidence in a time where there is much economic insecurity. The use of regional imagery in marketing is often engaged to denote quality of product and stimulate under-developed areas in Ireland (Henchion \& McIntyre, 2000). Alternative food systems highlight the social embeddedness of the economy. That is, they facilitate an element of moral awareness, community, personal relationships, and reciprocal exchange in the market (Sage, 2003). It is an added value that can be commodified.

The Irish Food Board's "Origin Green" initiative embodies this relationship to benefit the Irish economy, but several privately-owned grocers and food brands are adopting the approach as well. German-owned Irish discount grocer Aldi launched a "Love Ireland" campaign in 2012 to lend itself a sense of authenticity and quality by encouraging customers to buy locally and support Irish farmers and businesses (Barrington, 2012). EUROSPAR's "Yes to Irish!" campaign attempts the same (Retail News, 2011). Likewise, dozens of Irish brands came into cooperation in 2009 to form the "Love Irish Food" association, specifically to promote Irish products and protect Irish jobs (Cullen, 2010; Love Irish Food, 2014). All of these efforts rely heavily on mobilizing images of family, nationalism, nostalgia, and a romanticized Irish countryside. And they work. The campaigns have thus far been quite successful, increasing sales dramatically by tapping into the Irish population's desire to support the local economy as well as the perception that local Irish products are superior in quality (Guardian, 2013). Indeed, research conducted by Love Irish Food finds that over three quarters of Irish customers seek out Irishmade products when shopping. 


\section{Greenwashing Speciesism}

It is critical to acknowledge that, while the considerable agricultural growth in Ireland has brought wealth and independence to Irish farmers, these benefits have been unevenly experienced. Indeed, some researchers point to reforms such as the aforementioned Common Agricultural Policy as exploitative and stratifying (Crowley, 2006). Corporatized and productivity-oriented, this modern Irish agri-food sector has unfortunate consequences for Nonhuman Animals living in Ireland, too, as agriculture moved from subsistence to surplus. In addition to reinvigorating domestic consumption, evocations of Irish regionalism and postspeciesist imagery of happy, healthy, and consenting Nonhuman Animals have been successfully promoted to the effect of significantly increasing the international market's interest in Irish animal products (Henchion \& McIntyre, 2000) and thereby the number of Nonhuman Animals who will be exploited. While nonhuman domesticates experience unimaginable violence in farms of all make, smaller farms are less able to compete as larger, intensive operations flourish under new agricultural policies (Crowley, 2006). Intensive farms equate to more intensive oppression, as well as more victims.

As modern Irish agricultural policy exacerbates human inequality, widening the gap between the haves and have-nots among farmers, so, too, is it worsened for Nonhuman Animals whose output and death tolls shoot ever higher. The encroachment of large farms brought not just growth in Nonhuman Animal production, but also the environmental degradations inherent to the practice. Indeed, Ireland's export-focused agrarianization is increasingly industrialized and its ownership concentrated. In 2014, the overall value of "meat" and "livestock" export rose by 3\%. Violence against cows, in particular, undergirds a large part of this growth. Irish cow's flesh is 
available in more countries than any other nation's "beef" (Bord Bia, 2015). Just before The Great Famine, the Irish cow population was 1.8 million (Clarkson \& Crawford, 2001). Today that population has increased by three and a half times to 6.3 million (Central Statistics Office, 2015). Despite the remarkable growth the food sector has already experienced, the Irish state at the time of this writing hopes to further increase exports to the tune of 19 billion euros by 2025 under its "Food Wise" 10 year initiative. The primary focus of Food Wise 2025 is "meat," dairy, and "seafood" (Department of Agriculture, Food and the Marine, 2015).

Because expected growths in export will necessitate even greater growth in the Irish Nonhuman Animal population and the environmental impacts of increased flesh and dairy production are likely to be significant, some have criticized the Irish strategy as dangerous (Burke-Kennedy, 2015; Crowley, 2006). The Department of Agriculture, Food and the Marine (DAFM) projects that much of the growth will come from technological advancements and not from an increase to the number of Nonhuman Animals. While this may mollify environmental impacts, it will nonetheless ensure greater strain on Nonhuman Animals who will be forced (and genetically manipulated) to produce in greater capacities. Furthermore, despite the Irish focus on “environmentally-friendly" practices, "over-fishing," over-grazing, pollution, and the heavy use of water, grain, and energy are inherent to speciesist industries and will continue to threaten Irish ecosystems (Hogan, 2012). Greater international interaction resulting from increased trade has also opened the island to "invasive" species which further threaten natural systems (Montgomery et al., 2012). A number of free-living Nonhuman Animal communities have been significantly threatened by the encroachment of speciesist agriculture, such as otters, horseshoe bats, bottlenosed dolphins, natterjack toads, and a host of bird species (Crowley, 2006). 
Without further environmental protection commitments, Ireland's "green" branding could be jeopardized. Research warns that capitalist pressure on sustainable operations to compete, turn a profit, and find new markets can threaten the integrity of smaller industries and their ability to maintain control along supply channels (McDonagh \& Commins, 1999). Increasing privatization of agricultural production has also been undermining Ireland's long history of cooperative farming (Breathnach, 2000; Harte, 1997). Compounding this, the numerous health risks associated with animal production and consumption (an issue that might otherwise discourage consumption) have been mitigated by Ireland's strategic emphasis on local, value-added production (Mahon \& Cowan, 2004; O’Donovan \& McCarthy, 2002). In sum, while pasturebased, locally-produced "meat" and dairy systems are generally believed to be in the interest of both vulnerable humans and Nonhuman Animals (at least before they are inevitably killed), corrupting market forces, in tandem with the unavoidable health and environmental burdens associated with animal agriculture, challenge the integrity of this "sustainable" system (Wrenn, 2013).

Emerging Vegetarianism and Veganism in Modern Ireland

Although animal products dominate agricultural production, they are not the only areas of growth. Ireland's mushroom sector has also expanded significantly and is considered one of the most successful in the world (Teagasc, 2013). Thanks to subsidies and advertising programs, the industry now provides over 3,000 Irish jobs and is worth over a hundred million euros (McCall, 2015). The Mushroom Bureau (n.d.) bills mushrooms as a healthy alternative to animal protein and deliberately situates them within Ireland's growing interest with plant-based and vegetarian eating, even suggesting mushroom-based meals for "meat free Mondays." ${ }^{18}$ However, the 
mushroom sector's success also lies in its ability to make profitable the burdensome waste products from animal agriculture like chicken litter and cow's manure. This could mean that even vegetable alternatives to Ireland's animal-based economy will have difficulty disentangling from speciesist institutions. ${ }^{19}$

Nonetheless, an awareness to alternatives is alive in Ireland and the Irish Nutrition and Dietetic Institute (2004) even declares that a well-planned vegan or vegetarian diet is nutritiously sound. The April 9, 2016 edition of The Irish Times features a story on the consequences of Ireland's standard diet, warning readers: "Shifting away from excessively meat-based diets will benefit human health while reducing hunger among the poor, easing animal-welfare concerns and offering farmers a sustainable future" (Gibbons, 2016). While the number of vegans and vegetarians in Ireland is rather low, research does indicate an interest in plant-based eating. Commercial soy-based replacements have been in production in Ireland since 1981 (Shurtleff and Aoyagi, 2015), and about half of respondents in the North/South Ireland food consumption survey perceived a need to eat healthier (Kiely, 2001). Of those who did make changes to their diets, $70 \%$ worked to reduce fat intake while $67 \%$ worked to increase their fruit and vegetable intake. Other research finds that the Northern Irish (especially middle-aged women) are interested in organic foods based on concerns for the environment as well as their personal health, but they felt hindered by availability and cost (Davies et al., 1995). Indeed, healthful eating and plant-based diets can be difficult for many vulnerable groups. In an ironic flip from previous circumstances when plant-based diets were common in Ireland as a result of poverty and necessity, now the heavy consumption of Nonhuman Animal products in an industrialized society becomes pervasive for similar reasons. As was true in the past, Irish persons of lower socioeconomic status today are especially likely to be living in restrictive food environments 
which are conducive to poor quality of diet (Layte et al., 2011). Of relevance, not all interest in alternative consumption is related to health. Concerns with Nonhuman Animal welfare accounts for the vast majority of the Vegetarian Society of Ireland's membership, for instance (O'Brien, 2011). As was previously explored, the number of vegetarians in Ireland is quite small while the number of vegans is negligible, but this is changing.

In a story covering the growing vegan scene in Ireland, the Dublin Inquirer writes: "The vegans are coming” (Murphy, 2015). Vegan restaurants may be few, but vegetarian restaurants are not difficult to find in larger cities like Belfast, Dublin, Cork, Galway, and Limerick. As Murphy reports, demand for vegan options in restaurants is building. Cornucopia, Dublin's most prominent vegetarian restaurant in successful operation since 1986, he reports, is now almost exclusively vegan in an effort to meet demand. Even Cork's historic English Market, a leading representative of Ireland's local and sustainable branding initiative which is known for its selection of regionally-produced animal flesh, now includes a natural foods vendor. The English Market's restaurants also offer explicitly vegetarian menu items. In fact, all major grocery chains in Ireland now sell specialty vegan options, including soya milk and veggie patties. As one Irish vegetarian cookbook author explains it: "[ . . ] Ireland is in the middle of a culinary revolution" (Cotter, 1996, p.5). Even The Irish Catholic reports that "vegetarianism seems to be everywhere these days," providing readers an overview of vegetarian and vegan ethics and offering advice on how to best transition to the diet (Keery, 2014). The culmination of Ireland's vegan metamorphosis is evidenced in the 2015 arrival of Dublin Vegfest. Held on World Vegan Day (November $1^{\text {st }}$ ), the festival celebrates vegan food, culture, and anti-speciesism ethics. As one participant reminisced, "One of the things I remember most of the day is the number of Irish activists who came up saying words to the effect: 'where have all these vegans come from?' 
They were remarking on the huge numbers of people who no-one active in the Irish movement had seen before [ ... ]" (Yates, 2015). Sealing this successful year was Guinness's announcement that same month that the legendary brew and popular symbol of Irish cuisine would no longer be made with nonvegan ingredients extracted from the bodies of fish. This change in recipe, the company insists, comes from its desire to market the beer as suitable for vegans and vegetarians (Stack, 2015).

\section{The Irish Nonhuman Animal Rights Movement}

\section{Victorian Intersectional Advocacy}

Importantly, Ireland's flirtation with veganism is not just a matter of diet, but also of politics. The British Nonhuman Animal rights movement that emerged in the early $19^{\text {th }}$ century was dependent on Irish agitation. Irish politician Richard Martin, for instance, succeeded in passing the 1822 Cruel Treatment of Cattle Act in the United Kingdom, one of the first Nonhuman Animal rights laws in the West. He further campaigned against a number of especially cruel forms of speciesism and was also partially responsible for the formation of the first Society for the Prevention of Cruelty to Animals (SPCA), as the 1822 "Martin's Act" placed the power of prosecution in the hands of the public and thus necessitated some degree of organization (Phelps, 2007).

The behemoth of Victorian campaigning Frances Power Cobbe was Irish born as well. In addition to her social reform and women's rights work, she founded the National AntiVivisection Society (NAVS) and later the British Union for the Abolition of Vivisection (BUAV) when she determined that NAVS had lost its effectiveness and radical edge (Phelps, 2007). Both organizations are still in successful operation today. Anglo-Irish nationalist 
Charlotte Despard was also deeply engaged in vegetarianism and anti-vivisection in addition to her socialist, feminist, and anti-prison work, as was prominent Irish revolutionary and feminist Eva Gore-Booth (Leneman, 1997). In fact, a number of feminist activists of this era worked for Irish Independence in addition to their Nonhuman Animal advocacy (O'Connor, 2010). These activists understood the connections between speciesism, sexism, and colonialism to be deeply related systems of oppression, with vegetarianism acting as a form of resistance. This was particularly salient for Ireland, which, like many other British colonies, was feminized and denigrated as weak and inferior for its plant-based eating, while Britain's “beef” eating was taken as evidence to its strength and superiority (Adams, 2000; Kellogg, 1923).

\section{Modern Irish Advocacy}

Today, Ireland also hosts many indigenous organizations, and a number of groups specifically catering to concerns with anti-speciesism and veganism have emerged in the new millennium. As with other developed nations, this social movement space typically sees much larger, professionalized organizations attending primarily to dog and cat welfare or to issues facing popular free-living animals, while medium-sized organizations with some degree of professionalization focus more so upon food animals, but also free-living and other at-risk species. A number of less organized, unprofessionalized grassroots groups also exist, usually with a more radical, vegan-centric focus.

The Irish Society for the Prevention of Cruelty to Animals (ISPCA) is the largest animal welfare charity on the island. Established in 1949, it now hosts 20 affiliated member societies across the counties. ${ }^{20}$ The ISPCA and other welfare groups in Ireland enjoy state support and can receive large grants to fund operations (The Irish Times, 1998). As with large welfare 
organizations in the United States and the United Kingdom, the ISPCA has been unclear on its position regarding those species commonly exploited by industries and elites (Kiernan, 1999). This hesitant stance has created tension with more rights-based organizations. Likewise, the Irish Wildlife Trust (IWT) is inconsistent in its protection of free-living animals, denouncing "hunting" and badger "culling," for instance, but condoning killing as an option for deer "management." ${ }^{21}$ Groups such as the Irish Whale and Dolphin Group (IWDG) are even further species-specific. The IWDG monitors regional cetacean communities and was instrumental in achieving sanctuary status for Irish Waters in $1991 .{ }^{22}$ County Cork's Donkey Sanctuary is a popular visitor's attraction and, as of this writing, has rescued over 4,000 donkeys since its founding in $1987 .{ }^{23}$ Not all sanctuaries in Ireland are single-issue. With a more explicitly antispeciesist framework, Eden Farm Sanctuary cares for a number of nonhuman refugees while also engaging in public vegan education. ${ }^{24}$ In 2015, it launched Ireland's first large scale public awareness campaign advocating a vegan lifestyle across busses, billboards, and other public spaces (O’Reilly, 2015).

Irish groups with interests beyond harm reduction tend to be much more political and progressive in agenda. Formed in 1994, the Animal Rights Action Network (ARAN) resembles many other established British and American rights-based organizations that rely heavily on fundraising and focus on a number of anti-speciesist single-issue campaigns. ${ }^{25}$ ARAN regularly hosts public demonstrations in Dublin on familiar issues such as circuses and the live export of Nonhuman Animals for slaughter. Also based in Dublin, the Vegan Society of Ireland (also known as Vegan Ireland) launched in 2009 and, unlike its American and British counterparts, explicitly promotes veganism within an anti-speciesist framework. ${ }^{26}$ Formed in 1978 , the much older Vegetarian Society of Ireland (VSI) is a registered charity that also heavily supports vegan 
aims and concerns itself with ethical issues beyond veganism as a diet such as Nonhuman Animal welfare (Hillis, 2012/2013) (an earlier incarnation, the Irish Vegetarian Society, was active much earlier in the era of Irish independence). ${ }^{27}$ The Vegetarian Society of Ireland hosts World Vegetarian Day in Dublin each September.

There is a lively grassroots presence in Ireland as well. A number of local meetup groups serve for socializing, pot lucking, or dining out. ${ }^{28}$ In addition to Dublin activity, a 2013 issue of The Irish Vegetarian makes mention of vegetarian groups in Clare, Galway, Kerry, Kilkenny, Northern Ireland, and Sligo. Cork Vegans exists in the southern part of the country, primarily focusing on supporting other vegans in navigating restaurants and accessing specialty vegan products (Slater, 2011). Active since about 2013, the Vegan Information Project (VIP) adheres to a more radical approach of abolitionist education which prioritizes anti-speciesism and antioppression values. ${ }^{29}$ It can be found tabling regularly in downtown Dublin.

The National Animal Rights Association (NARA) (formerly the Irish branch of the Coalition to Abolish the Fur Trade) was formed in 2005 and is also Dublin-based, vegan-centric, and grassroots. ${ }^{30}$ While this group mirrors the activities of the larger, professionalized organizations in that it relies on single-issue campaigning and public demonstrations, it is opposed to reform and draws on the "direct action" approach to anti-speciesism. This is an approach that tends to advocate or otherwise allow for aggressive or illegal tactics. ${ }^{31}$ There is also ALiberation in Dublin, which more closely adheres to the direct action approach, though it appears to be less active than NARA. ${ }^{32}$ Based in County Westmeath, the Irish Council Against Blood Sports (ICABS) has been advocating against "hunting," "coursing," "fighting," and some forms of trapping. Formed in 1966, it once operated support groups in major cities across the 
country. It relies heavily on petitioning today, though it engaged more direct interference with these speciesist practices in the past. ${ }^{33}$

\section{Anti-Speciesism and the Irish State}

Anti-speciesism agitation in Ireland is considerably robust, but these efforts have been just as robustly countered. Ethnographic research in Irish movement ranks unveils a belief that the Irish protest imagination is inherently apathetic or discouraged by state repression (Yates, 2011). Others point to research emphasizing the stagnating effect of low cultural modernization in the wake of colonialism, or the tenuousness of Irish industry which necessitated attention paid to survival over progress (Tovey and Share, 2000). However, the groundswell response to landlordism, gay marriage, abortion, and water charges in addition to a rich history of Irish protest against British imperialism tells another story. Indeed, Ireland's oppressive history under British rule may actually have sharpened its concern for social justice (Baker, 1990). For that matter, Ireland's traditional culture may not always act as an impediment to social progress. It can also be employed as a powerful and resonant framework for protecting and respecting nature and its inhabitants.

Although the Irish vegan movement may not exist to the same scale as its British and American counterparts, collective action on behalf of other animals is probably proportionate given Ireland's limited geographic space and small population. In any case, it is enough activity for the Irish state to take some notice. Similar to collectives working in other parts of the West, direct action activists in Ireland have met with police surveillance, intimidation, and arrest (Fitzgerald, 2011). Peaceful protestors, too, are also experiencing similar state management and interference (Yates, 2011). As in the United States and many parts of Europe, anti-speciesism 
advocacy of any kind is increasingly considered a terrorist act. Change is happening, however, as is evidenced in the ban on Nonhuman Animal use in Irish circuses. When a German circus visited Ireland in 2016 with a large number of nonhumans in tow, it sparked considerable protest. ${ }^{34}$ Nonhuman Animal rights activism (and activism in general) tends to be negatively covered (if covered at all) in mainstream media spaces (Freeman, 2009). Hence, it is quite telling that the circus protests garnered extensive and positive press coverage.

The resonance of anti-speciesist and vegan claimsmaking has fluctuated based on economic conditions and socio-political circumstances. The Irish reliance on animal flesh in diet and export reflects its new relative wealth in the global system and a determination for selfsufficiency. It also accounts for the state's interest in repressing anti-speciesism activism. Yet, Ireland's deepening relationship with other nations and cultures has popularized veganism and plant-based eating to some extent. In addition to Irish advocacy efforts and culinary advances as previously discussed, this consciousness is also surfacing in the emerging realm of Irish critical animal studies (Kirkpatrick \& Faragó, 2015; O'Connor, 2010). This field explores how Ireland's own heritage has encouraged relationships and respect with other animals. But modernity, too, can offer some connections. Urbanization may have increased the use of Nonhuman Animals in food and science, but it has also diminished the popularity of some traditional institutions of speciesism. The ICABS writes of Ireland in 1996:

$[\ldots]$ there is the disappearance of the rural/urban divide. $[\ldots]$. No longer do country dwellers live their lives exclusively in their rural environment and it is no longer the case that city dwellers view the countryside as a different (even alien) environment. Country dwellers now have access to entertainment and leisure activities to an extent not possible 
a generation ago. "Country" pastimes like hare coursing and foxhunting are no longer the only diversions and they are losing support. (Ramsey \& March, 1996)

It is also worth noting that Christopher Fettes, founder of the Irish Green Party, is also the founder of the Vegetarian Society of Ireland (and former chairman of the Irish Anti-Vivisection Society). While its influence is limited in Irish government, the Green Party does include a strong position on Nonhuman Animal welfare in its policy. ${ }^{35}$ The Irish state, then, while deeply reliant on speciesist systems, is also experiencing some important resistance to its oppressive economic structures as made apparent by transforming values, a changing geography, and the hard work of a diverse advocacy community. Veganism is creeping into the Irish consciousness.

\section{Conclusion}

Ireland is often stereotyped as inherently incompatible with veganism. But Ireland is an island, not a vacuum. More than homegrown, Ireland's culture is also globally grown. Its intermingling with various invaders, traders, and immigrants has manifested a culture more diverse in values than is commonly acknowledged. This transferral of culture and capital has entrenched speciesism, but it has also created awareness to alternatives. Similar to other developed nations in the West, Ireland has absorbed concerns about the healthfulness and environmental impact of animal-based consumption. Ireland has also played an important role in the formation of the Nonhuman Animal rights movement, and it continues to participate with its own indigenous contributions to vegan and anti-speciesist activism today. Ireland exhibits a greater anti-speciesism consciousness that is generally given credit for.

Another concept often obscured from its legacy is the Irish intersection of human and nonhuman oppression in Ireland. While pre-colonial Irish society was certainly reliant on the 
oppression of Nonhuman Animals, this oppression would escalate dramatically with the imposition of British rule. The diet of Ireland's populace from prehistory until modernization in the $20^{\text {th }}$ century was largely plant-based. This diet would amplify under colonialism as animal products were shipped to England and became much too expensive for Ireland's poor. Recall that the versatility of the potato would be responsible for a dramatic increase in the Irish population in the $18^{\text {th }}$ and $19^{\text {th }}$ centuries, but this reliance also created extreme vulnerability in the context of colonialism. As one historian describes it: "The collapse of Ireland's population along with the potato crops only emphasizes how important a lacto-vegetarian diet was to most Irish people” (Cotter, 1996, p.5). Given this history, it is strange that Ireland's dietary heritage is today eclipsed by stereotypes of flesh-eating, as the relationship between plant-based eating and Ireland's development is so tightly connected. It is possible that modern Ireland's carnivorous identity is not so much an accident as it is a result of government and industry campaigning to normalize and encourage speciesist consumption. The Irish state is heavily vested in speciesism and may reconstruct or obscure any Irish history that is adverse to its economic interests.

As with many other human societies, Ireland's vegan heritage remains bound with that of its nonvegan, and it is difficult to identify an unadulterated anti-speciesist ethic in a world so steeped in oppression and inequality. Again, Ireland's "meat" culture today stems from that very oppression. It is a legacy of British colonization, one that has strengthened over many years and economic developments. It ensured that millions of Ireland's poor would starve or flee while Nonhuman Animals were raised on British-owned Irish land to be killed and exported to feed the privileged. Perhaps, then, it would be accurate to understand Ireland as a "land of meat and potatoes" insofar as Irish suffering and resilience will always be bound to the killing of animals for absentee elites, the meager consolation potatoes would bring, and the struggles of the 
vulnerable in a speciesist, postcolonial society. The state today has embraced "meat" and dairy production with ambitious plans of expansion in international markets, banking on the world's romantic fascination with the Irish rural idyll despite concerns that the strategy will have serious consequences for human, nonhuman, and environmental wellbeing. Indeed, as speciesist agriculture explodes under productivist policies, Nonhuman Animals — both domesticated and

free-living - have been further oppressed, and inequality has dramatically increased among Irish farmers as well (Crowley, 2006).

Fortunately, there are pockets of anti-speciesist activism that bring renewed attention to nonviolent, plant-based eating and alternative economies. Ireland's quickly expanding mushroom sector has positioned itself as relevant to increasing interest in vegetarianism, while vegan alternatives are becoming more and more familiar to Irish grocery stores and restaurants. The rich variety of Nonhuman Animal welfare and rights organizations across the country also speaks to another side of Irish identity, one that is less about "meat and potatoes" and more relevant to contemporary social justice efforts. VIP spokesperson and sociologist Roger Yates (2013) declares: "Not long ago, people said that Ireland was not ready for veganism. Well, it is now."

\section{Notes}

1. Euphemistic or otherizing language that objectifies Nonhuman Animals is placed in quotation marks to denote its contested nature.

2. The term "Nonhuman Animal(s)" is capitalized to denote their status as a distinct and politically relevant social group. 
3. Some species once extinct in Ireland, such as red squirrels, have been repopulated. Not all of the species listed here went extinct in ancient Ireland; some survived into the industrial age.

4. Ireland's famous giant elk appears to have gone extinct due to climactic changes before the arrival of humans approximately 9,000 years ago and was not a victim of human oppression (Barnosky, 1986).

5. Cú Chulainn was also fabled to have gained his superhuman status from the killing of a formidable guard dog and then offering to take the place of the lost animal (he is sometimes referred to as the "Hound of Ulster" for this reason). Later in the tale, his demise is thought a result from his "cannibalistic" consumption of dog's flesh and killing of an otter (known as a “water dog”) before battle, which apparently weakened him (Sjoestedt, 2000).

6. Wren's Day is also rooted in Irish pagan heritage with wrens used in augury and midwinter's festivals while also surfacing in mythology (Spence, 1999). The event involved the capture of wrens who were paraded door-to-door through villages on sticks before being killed.

7. Information on Catholic Concern for Animals can be found online at: http://catholicanimals.org/ and http://www.all-creatures.org/ca/. Additional information on the relationship between Catholicism and anti-speciesism can be found in the CCA's magazine publication, The Ark, which is available on CCA's website.

8. The first newsletter of the Vegetarian Society of Ireland in 1978 makes mention of a CCA branch in Ireland. Many Nonhuman Animal rights and welfare organizations of the 1970s and 1980s were democratically operated and locally based in this way before eventually centralizing in the 1980 s or 1990 s as their wealth and stability was secured (Wrenn, 2016). I was not able to locate any recent mention of branches. 
9. Salaman (1985) notes that the delay of technological advancements in farming had negative consequences for domesticated animals. Sheep's hair was plucked by hand, for instance, and horses pulled ploughs by the tail, a practice the English unsuccessfully sought to eradicate until well into the $19^{\text {th }}$ century.

10. The Great Famine decimated the poorer classes, who were more likely to marry young and to have large families.

11. Although the Quakers often offered vegetarian fare and seeds for vegetable gardening, another important part of their relief strategy involved the development of Ireland's "fishing" industry (Hatton, 1993). The Quakers also operated soup kitchens, and contemporary reports of their fare suggest that "meat" was thought an essential ingredient for achieving quality. Apparently, devout Irish Catholics would refuse this nonvegetarian soup on Fridays, even when facing starvation. Furthermore, the Quakers were also heavily involved in cereal and corn production and the Irish disaster may have presented an opportunity for profiteering, which is thought to explain why these particular goods were pushed so heavily (Wells, 1994).

12. In her 1835 publication, Nature's own book, Nicholson lists rules for her temperance boardinghouse: "No animal food of any kind (including fowl and fish—salt and fresh) should be brought upon the breakfast table; nor should any such food be eaten by any of the boarders for their breakfast" (p. 15). However, the establishment does not appear to be strictly vegetarian. "Those who eat flesh" are allowed to have a small amount of it at dinner. Nicholson also provides advice written by celebrity reformer Sylvester Graham on the appropriateness of animal flesh which concedes for the consumption of some species. Eggs and butter are allowed at breakfast, but in limited quantities. Of butter, she writes, "Butter, at best, is a questionable article, and should be very sparingly used by the healthy, and not at all 
by the diseased" (p.16). Milk (presumably from animal sources) is regularly included in the recipes provided. Horseback riding is also listed as an option for fulfilling the boardinghouse exercise regimen. "Horseback riding is very good, if well regulated," Nicholson advises (p.21). Although a number of plant-based enterprises of the $19^{\text {th }}$ century did consider the welfare of other animals as a reason for eschewing Nonhuman Animal products and labor, Nicholson's was not one of them. Her approach appears to be primarily grounded in concerns for human physical and spiritual health, advocating simplicity of diet to reduce the contraction of disease, discourage vice, and increase godliness among adherents.

13. Nibert further argues that the institution of domestication itself is at the root of inequality and the suffering of humans and nonhumans alike. Because so much of Ireland's development has been based in the domestication and exploitation of other animals, there are likely further implications for Irish human/nonhuman relationships to be derived beyond the era of English ascendency that Nibert identifies. For instance, O’Connor (2010) and Halley (2012) explore these Irish intersections from a feminist perspective, noting the entangled experience of women and other animals.

14. The colonization of Ireland not only harmed humans and nonhumans of the island to increase "meat" production for Britain, but this "meat" and dairy industry was also necessary for supporting the British slave trade in the Caribbean (Ross, 1987) and the bloody Napoleonic wars (Cowan and Sexton, 1997).

15. Suspicious dogs were preemptively killed in all manner of gruesome executions, particularly in the hot days of summer when rabies was thought to proliferate. Other dogs underwent painful surgeries of the tongue as a means of lessening their danger to humans should they contract the disease. Dogs were already highly vulnerable to human violence as they were 
thought a nuisance and blamed for interfering with other speciesist institutions such as “hunting” and Nonhuman Animal agriculture (Griffin, 1994).

16. English propaganda of this time also described the Irish as cannibals and partakers of blood rituals (Fitzpatrick, 2004). Ancient Greeks and Romans described Ireland as cannibalistic as well (Freeman, 2001).

17. The discovery of equine DNA in imported flesh intended for human consumption has been cited as a source of distrust among Irish customers (Bord Bia 2013), as have outbreaks of foot-and-mouth disease, Bovine Spongiform Encephalopathy (mad cow disease), and dioxin contamination in the 2008 Irish "pork" crisis that resulted in a massive international recall (Bánáti, 2011).

18. See justaddmushrooms.com

19. Ireland has historically used seaweed as a fertilizer (Friel \& Nolan, 1996), which could act as an ethical and sustainable replacement for animal manure.

20. A brief history of the ISPCA is available on its website: http://www.ispca.ie/who_we_are/

21. IWT position statements can be found on its website: http://www.iwt.ie/about-us/iwt-policy

22. IWDG can be found online at http://www.iwdg.ie

23. The Donkey Sanctuary can be found online at: http://www.thedonkeysanctuary.ie/

24. Eden Farm Sanctuary can be found online at: http://www.edenfarmanimalsanctuary.com/

25. ARAN maintains a website at: http://www.aran.ie/, though its Facebook page is more regularly updated at the time of this writing: https://www.facebook.com/pages/ARANAnimal-Rights-Action-Network/155913217835225

26. Vegan Ireland can be found online at: http:/www.vegan.ie/about-us/ 
27. The Vegetarian Society of Ireland can be found online at: http://www.vegetarian.ie/about/. Leneman (1997) makes mention of the Irish Vegetarian Society when describing the activities and affiliations of early vegetarian suffragettes. I contacted the Vegetarian Society to inquire of its earlier history and it was not able to verify.

28. Some of these meetups are affiliated with or are supported by the larger organizations.

29. VIP can be found online at: http://veganinformationproject.cf/

30. NARA can be found online at: http://www.naracampaigns.org/ and https://www.facebook.com/NARAcampaignsIRELAND

31. From the guidelines posted on the NARA website: "As members of N.A.R.A., we adhere to A.R. strategy and protocol. This includes; being assertive in confrontational situations and acquiring knowledge on demo topics to respond to the public and to maintain the integrity of the group." The guidelines also emphasize "sticking together" and prioritizing the organization, and the website encourages prisoner support for incarcerated activists. This could be said to reflect the ethos of other direct action organizations that often come into conflict with the police and are plagued with surveillance and snitching (Wrenn, 2016). Further evidence to its direct action approach is provided in the group's Facebook page which shares images of protest signs that refer to targets as "scum" or "sick," images of protesters wearing Animal Liberation Front paraphernalia (the Western movement's most notorious direct action organization), and images of demonstrations where activists surround private resistances to picket and chant.

32. ALiberation can be found online at: http://aliberation.vegaplanet.org/

33. ICABS and its archive of newsletters can be found online at: http://www.banbloodsports.com/ 
34. See the March 23, 2016 edition of The Irish Mirror, "Six people arrested after brawl between circus members and animal rights activists in Dublin.” Available here:

http://www.irishmirror.ie/news/irish-news/six-people-arrested-after-brawl-7617274. See also the March 18, 2016 episode of Liveline with Joe Duffy:

http://www.rte.ie/radio/utils/radioplayer/rteradioweb.html\#!rii=b9\%5F10547459\%5F53\%5F $18 \% 2 \mathrm{D} 03 \% 2 \mathrm{D} 2016 \% 5 \mathrm{~F}$

35. More information on Fettes and the Irish Green Party can be found on the party's website: www.greenparty.ie

\section{Works Cited}

Adams, C. (2000). The sexual politics of meat: a feminist vegetarian critical theory. London: Continuum.

Ahlstrom, D. (2011, September 8). Solving a 2,000-year-old death. The Irish Times. Retrieved from: http://www.irishtimes.com/news/science/solving-a-2-000-year-old-death-1.593646

Baker, S. (1990). The evolution of the Irish ecology movement. In W. Rüdig (Ed.), Green politics. Rotterdam: Erasmus University Press.

Bánáti, D. (2011). Consumer response to food scandals and scares. Trends in food Science \& Technology, 22 (2-3), 56-60.

Barrington, B. (2012, December 9). Aldi launches advertising campaign focused on buying Irish. Business \& Leadership. Retrieved from:

http://www.businessandleadership.com/marketing/item/37131-aldi-launches-advertising

Barnosky, A. (1986). "Big game” extinction caused by late Pleistocene climactic change: Irish elk (Megloceros giganteus) in Ireland. Quaternary Research, 25 (1), 128-135. 
BBC Alba. (2016). Banished women. Retrieved from: http://www.bbc.co.uk/programmes/b07b367s

Bergholm, A. (2005). Academic and neopagan interpretations of shamanism in Buile Suibhne: a comparative approach. Studia Celtica Fennica, 2, 30-46.

Bord Bia. (2015). Export performance \& prospects 2014-2015. Dublin: Irish Food Board.

Bord Bia. (2013). Retaining loyalty to Irish brands. Dublin: Irish Food Board.

Breathnach, P. (2000). The evolution of the spatial structure of the Irish dairy processing industry. Irish Geography, 33 (2), 166-184.

Burke-Kennedy, E. (2015, July 3). Analysis: agri-food roadmap fails to assess environmental impact. The Irish Times. Business. Retrieved from: http://www.irishtimes.com/business/agribusiness-and-food/analysis-agri-food-roadmapfails-to-assess-environmental-impact-1.2271717

Caulfield, S. (2013). Ceide fields: Europe's oldest surviving dairy fields? In M. Jebb and C. Crowley (Eds.), Secrets of the Irish landscape (pp. 95-100). Cork: Atrium.

Casey, C. \& F. Ryan. (2015, April 1). The Book of Kells: 'The most purely Irish thing we have' - James Joyce. The Irish Times. Retrieved from: http://www.irishtimes.com/opinion/thebook-of-kells-the-most-purely-irish-thing-we-have-james-joyce-1.2159952

Central Statistics Office. (2012). Meat supply balance 2011. Dublin: Central Statistics Office. Central Statistics Office (2015). Livestock survey December. Retrieved from: http://cso.ie/en/releasesandpublications/er/lsd/livestocksurveydecember2014 Chozick, A. (2013, March 15). Boom over, St. Patrick's isle is slithering again. The New York Times. Retrieved from: http://www.nytimes.com/2013/03/16/world/europe/boom-over-stpatricks-isle-is-slithering-again.html?_r=0 
Clarkson, L. \& E. Crawford. (2001). Feast and famine: a history of food and nutrition in Ireland 1500-1920. Oxford: Oxford University Press.

Collins, L. (2015). 'Our sep'rate natures are the same': reading blood sports in Irish poetry of the Long Eighteenth Century. In K. Kirkpatrick \& B. Faragó (Eds.), Animals in Irish literature and culture (pp.1-12). London: Palgrave Macmillan.

Connolly, M. (2011, November 11). The story of Ireland: the age of conquest [Television broadcast]. London: British Broadcasting Corporation.

Coogan, T. (2013). The famine plot: England's role in Ireland's greatest tragedy. London: Palgrave Macmillan.

Cotter, P. (1996). Irish vegetarian cookery. Cork: Killeen Books.

Cowan, C. and R. Sexton. (1997). Ireland's traditional foods: an exploration of Irish local and typical foods and drinks. Dublin: Teagasc, The National Food Centre.

Crónín, D. (1995). Early medieval Ireland, 400-1200. New York: Routledge.

Crowley, E. (2006). Land matters: power struggles in rural Ireland. Dublin: The Lilliput Press.

Cullen, P. (2010, September 28). Love Irish Food campaign hailed. The Irish Times. Retrieved from: http://www.irishtimes.com/news/love-irish-food-campaign-hailed-1.864728

Curtis, L. (1997). Angels and apes: the Irishman in Victorian caricature. DC: Smithsonian Institution Press.

D’Arcy, C. (2015, July 20). Nearly 225,000 animals used for scientific tests in 2014. The Irish Times. Retrieved from: http:/www.irishtimes.com/news/science/nearly-225-000-animalsused-for-scientific-tests-in-2014-1.2290257

Davies, A., A. Titterington, \& C. Cochrane. (1995). Who buys organic food?: a profile of the purchasers of organic food in Northern Ireland. British Food Journal, 97 (10), 17-23. 
Deckha, M. (2013). Welfarist and imperial: the contributions of anticruelty laws to civilizational discourse. American Quarterly, 65 (3), 515-548.

Department of Agriculture, Food and the Marine. (2015). Local roots, global reach: Food Wise 2025: a 10-year vision for the Irish agri-food industry. Retrieved from:

http://www.agriculture.gov.ie/media/migration/agri-

foodindustry/foodwise2025/report/FoodWise2025.pdf

Donnelly, J. (1971). Cork market: its role in the nineteenth century Irish butter trade. Studia Hibernica, 11, 130-163.

Earwood, C. (1997). Bog butter: a two thousand year history. The Journal of Irish Archaeology, $8,25-42$.

Fitzgerald, J. (2011). Bad hare days: one man's fight against a cruel blood sport. Kilkenny: Callan Press.

Fitzpatrick, J. (2004). Food and foreignness in Sir Thomas More. Early Theatre, 7 (2), 33-47.

Food and Drink Industry Ireland. (2015). Meat industry overview. Retrieved from:

\section{http://www.fdii.ie/meat}

Freeman, C. (2009). This little piggy went to press: the American news media's construction of animals in agriculture. The Communication Review, 12 (1), 78-103.

Freeman, P. (2001). Ireland and the classical world. Austin: University of Texas Press.

Friel, S. \& G. Nolan. (1996). Changes in the food chain since the time of the Great Irish Famine. Galway: National Nutrition Surveillance Centre.

Gibbons, J. (2016, April 9). Meat is madness: why it leads to global warming and obesity. The Irish Times. Retrived from: http://www.irishtimes.com/life-and-style/food-anddrink/meat-is-madness-why-it-leads-to-global-warming-and-obesity-1.2602027 
Guardian, G. (2013, March 3). Good news for local suppliers and farmers as Aldi continues to grow. Irish Independent. Retrieved from:

http://www.independent.ie/regionals/goreyguardian/news/good-news-for-local-suppliersand-farmers-as-aldi-continues-to-grow-29124164.html

Green, M. (1992). Animals in Celtic life and myth. New York: NY: Routledge.

Griffin, B. (1994). 'Mad dogs and Irishmen': dogs and rabies in the eighteenth and nineteenth centuries. Ulster Folklife, 40, 1-15.

Grogan, E., G. Eogan, J. Rees, V. Butler, \& J. Henderson. (1987). Lough Gur excavations by Seán P. Ó Ríordáin: further Neolithic and Beaker habitations on Knockadoon. Proceedings of the Royal Irish Academy. Section C: Archaeology, Celtic Studies, History, Linguistics, Literature, 87 (C), 299-506.

Halley, J. (2012). The parallel lives of women and cows: meat markets. London: Palgrave Macmillan.

Harte, L. (1997). Creeping privatization of Irish co-operatives: a transaction cost explanation. In J. Nilsson \& G. van Dijk (Eds.), Strategies and structures in the agro-food industries (pp.32-54). Assen: Van Gorcum \& Comp.

Hatton, H. (1993). The largest amount of good: Quaker relief in Ireland, 1654-1921. Montreal: McGill-Queen's University Press.

Heffernan, P. (2014). The Galway statement on the establishment of a Trans-Atlantic ocean research alliance. In E. Svensson \& L. Pendleton (Eds.), Transitioning to a new blue economy: proceedings of the December 2013 economics of the ocean summit (pp. 36-38). Durham, NC: Duke University. 
Henchion, M. \& B. McIntyre. (2000). Regional imagery and quality products: the Irish experience. British Food Journal, 102 (8), 630-644.

Hickey, K. (2015, July 17). The history of Irish cuisine - over 8,000 years old and hardly any potatoes. Irish Central. Retrieved from: http:/www.irishcentral.com/culture/fooddrink/The-history-of-Irish-cuisine---over-8000-years-old-and-hardly-any-potatoes.html

Hillis, G. (2012/2013, Winter). A trip down memory lane. The Irish Vegetarian, 137, 6.

Hogan, T. (2012, June 26). Native animals 'at risk of extinction' as pollution and over-fishing take toll. New Irish News. Retrieved from: http://www.independent.ie/irish-news/nativeanimals-at-risk-of-extinction-as-pollution-and-overfishing-take-toll-26868955.html

Irish Nutrition and Dietetic Institute. (2004). A guide to vegetarian eating. Retrieved from: http://www.irishhealth.com/clin/documents/vegetarian.pdf

Kaufman, R. (2014). Kaufman green guide: Dublin. Self-published.

Kellogg, J. (1923). The natural diet of man. Battle Creek: Modern Medical Publishing Company.

Kiely, M. (2001). Summary report. North/South Ireland food consumption survey. Dublin: Food Safety Promotion Board.

Kiernan, P. (1999, Spring/Summer). ISPCA branch may face dis-affiliation over blood sports stance. Animal Watch, 11 .

Kinealy, C. (2001). The Great Irish Famine: impact, ideology and rebellion. London: Palgrave Macmillan.

King, C. \& L. Kennedy. (1994). Irish co-operatives: from creameries at the crossroads to multinationals. History Ireland, 4 (2).

Kinmonth, C. (2006). Irish rural interiors art. New Haven, CT: Yale University Press. 
Kirkpatrick, K. \& B. Faragó (2015). Animals in Irish literature and culture. London: Palgrave Macmillan.

Keery, A. (2014, July 17). Becoming vegetarian is increasingly popular. The Irish Catholic. Retrieved from: http://www.irishcatholic.ie/article/becoming-vegetarian-increasinglypopular

Kraut, A. (1994). Silent travelers: germs, genes, and the 'immigrant menace.' Baltimore, MD: The Johns Hopkins University Press.

Laurence, A. (1988). The cradle to the grave: English observation of Irish social customs in the seventeenth century. The Seventeenth Century, 3 (1), 63-84.

Layte, R., J. Harrington, E. Sexton, I. Perry, J. Cullinan, \& S. Lyons. (2011). Irish exceptionalism? Local food environments and dietary quality. Journal of Epidemiology and Community Health, 65, 881-888.

Leahy, E., S. Lyons, \& R. Tol. (2010). National determinants of vegetarianism. Working paper. Dublin: Economic and Social Research Institute.

Leneman, L. (1997). The awakened instinct: vegetarianism and the women's suffrage movement in Britain. Women's History Review, 6 (2), 271-287.

Lobell, J. \& S. Patel. (2010, May/June). Clonycavan and Old Croghan men. Archaeology, 63 (3). Retrieved from: http://archive.archaeology.org/1005/bogbodies/clonycavan_croghan.html Love Irish Food. (2014). About us. Retrieved from: http://www.loveirishfood.ie/about-us/ Lucas, A. (1960). Irish food before the potato. Folk Life, 3 (2), 8-43.

Mac Coitir, N. (2010). Ireland's animals: myths, legends \& folklore. Cork: Collins Press. Mac Coitir, N. (2006). Irish wild plants: myths, legends \& folklore. Cork: Collins Press. 
MacConnell, C. (2016, March 10). Everything you know about the St. Patrick's Day shamrock is a lie. Irish Central. Retrieved from: http://www.irishcentral.com/opinion/others/truthsabout-the-shamrock-for-st-patricks-day-everything-you-think-you-know-about-thesymbol-of-irishness-is-a-lie-198438781-238173881.html

Mahon, D. \& C. Cowan. (2004). Irish consumers' perception of food safety risk in minced beef. British Food Journal, 106 (4), 301-312.

McCall, B. (2015, February 2). Strong growth continues for mushroom industry. The Irish Times. Retrieved from: http:/www.irishtimes.com/sponsored/strong-growth-continuesfor-mushroom-industry-1.2085451

McDonagh, P. \& P. Commins. (1999). Food chains, small-scale food enterprises and rural development: illustrations from Ireland. International Planning Studies, 4 (3), 349-371.

Monk, M. (2013). The first farmers: who they were and how they lived. In M. Jebb and C. Crowley (Eds.), Secrets of the Irish landscape (pp. 103-111). Cork: Atrium.

Montgomery, I., M. Lundy, and N. Reid. (2012). 'Invasional meltdown': evidence for unexpected consequences and cumulative impacts of multispecies invasions. Biological Invasions, 14 (6), 1111-1125.

Morris, H. (1939). St. Martin's Eve. Folklore of Ireland Society, 9 (2), 230-235.

Murphy, D. (2015, June 2). The vegans are coming. Dublin Inquirer. Retrieved from: http://dublininquirer.com/2015/06/02/the-vegans-are-coming/

Murphy, M. (2015). Compassionate stranger: Asenath Nicholson and the Great Irish Famine. Syracuse, NY: Syracuse University Press.

Mushroom Bureau. (n.d.). Healthy eating with mushrooms [Resource guide/Campaign material]. Justaddmushrooms.com. 
Mussetter, S. (1977). An animal miniature on the monogram page of The book of Kells. Mediaevalia, 3, 119-130.

Nibert, D. (2013). Animal oppression \& human violence: domesecration, capitalism, and global conflict. New York: Columbia University Press.

Nicholson, A. (1835). Nature's own book. $2^{\text {nd }}$ ed. New York, NY: Wilbur \& Whipple Printers.

Newman, R. (2011). Brian Boru: King of Ireland. Cork: Mercier Press.

Noonan, K. (1998). 'The cruell pressure of an enraged, barbarous people': Irish and English identity in Seventeenth-century policy and propaganda. The Historical Journal, 41 (1), 151-177.

O'Brien, C. (2011, Autumn). Vegetarians in the UK and Ireland. The Irish Vegetarian, 133, 7.

O'Connor, M. (2010). The female and the species: the animal in Irish women's writing. Bern: Peter Lang AG, International Academic Publishers.

O’Donovan, P. \& M. McCarthy. (2002). Irish consumer preference for organic meat. British Food Journal, 104 (3/4/5), 353-370.

O’Kelly, M. (2001). Early Ireland: an introduction to Irish prehistory. Cambridge: Cambridge University Press.

O’Malley, P. (1990). Biting at the grave: the Irish hunger strikes and the politics of despair. Boston: Beacon Press Books.

O’Reilly, S. (2015, November 30). World vegan month in full swing. The College Tribune. Retrieved from: http://collegetribune.ie/world-vegan-month-in-full-swing/

Ó Ríordáin, S. \& M. MacDermott. (1949). Lough Gur excavations. The Journal of the Royal Society of Antiquaries of Ireland, 79 (1/2), 126-145. 
O’Toole, L. \& O'Flaherty. (2011). Out of sight, out of mind? On the trail of the forgotten Irish bird. Archaeology Ireland, 25 (1), 13-16.

Owen, J. (2014). Did St. Patrick really drive snakes out of Ireland? The National Geographic. Retrieved from: http://news.nationalgeographic.com/news/2014/03/140315-saintpatricks-day-2014-snakes-ireland-nation/

Pemberton, N. \& M. Worboys. (2007). Mad dogs and Englishmen: rabies in Britain, 1830-2000. London: Palgrave Macmillan.

Phelps, N. (2007). The longest struggle: Animal advocacy from Pythagoras to PETA. New York, NY: Lantern Books.

Pichler, R. \& G. Blackwell. (2007). How many veggies ... ? European Vegetarian Union. Retrieved from: http://www.euroveg.eu/lang/en/info/howmany.php

Poloczek, K. (2015). 'Their disembodied voices cry': marine animals and their songs of absence in the poetry of Sinéad Morrissey, Caitríona O’Reilly, and Mary O’Donoghue. In K. Kirkpatrick \& B. Faragó (Eds.), Animals in Irish literature and culture (pp.75-91). London: Palgrave Macmillan.

Public Record Office of Northern Ireland. (n.d.). The Great Irish Famine. Belfast: Public Record Office of Northern Ireland.

Pure Adventures Ireland. (2013, June 17). A vegan's survival guide to travelling in Ireland. The Huffington Post. Retrieved from: http://www.huffingtonpost.com/pure-adventurestravel/a-vegans-survival-guide-t_b_3455243.html

Ramsey, A. \& G. March. (1996, Summer). Chairman’s address. Animal Watch, 1.

Retail News (2011b, July/August). EUROSPAR: the super easy supermarket. Retail News, 3839. 
Ross, E. (1987). An overview of trends in dietary variation from hunter-gatherer to modern capitalist societies. In M. Harris \& E. Ross (Eds.), Food and evolution: toward a theory of human food habits (pp. 7-56). Philadelphia: Temple University Press.

Sailer, S. (1998). Suibne Geilt: puzzles, problems, and paradoxes. The Candian Journal of Irish Studies, 24 (1), 115-131.

Salaman, R. (1985). The history and social influence of the potato. Cambridge: Cambridge University Press.

Sage, C. (2003). Social embeddedness and relations of regard: alternative 'good food' networks in south-west Ireland. Journal of Rural Studies, 19, 47-60.

Shurtleff, W. and A. Aoyagi. 2015. History of soybeans and soyfoods in the United Kingdom and Ireland (1613-2015): extensively annotated bibliography and sourcebook. Lafayette, CA: Soyinfo Center.

Sexton, R. (1995). 'I'd ate it like chocolate!': the disappearing offal food traditions of Cork City. In H. Walker (Ed.), Disappearing foods: studies in foods and dishes at risk. Proceedings of the Oxford Symposium on Food and Cookery 1994 (pp. 172-188). Devon: Prospect Books.

Sexton, R. (1998). A little history of Irish food. Dublin: Gill and Macmillan Ltd.

Sexton, R. (2002). Food and drink at Irish weddings and wakes. In L. Mason (Ed.), Food and the rites of passage: Leeds symposium on food history (pp. 115-142). Devon: Prospect Books.

Sexton, R. (2013). Plant foods in Ireland before AD 1500. In M. Jebb and C. Crowley (Eds.), Secrets of the Irish landscape (pp. 155-163). Cork: Atrium. 
Simoons, F. (1994). Eat not this flesh: food avoidances from prehistory to the present. Madison, WI: The University of Wisconsin Press.

Sjoestedt, M. (2000). Celtic Gods and Heroes. Mineola, NY: Dover Publications, Inc.

Slater, B. (2011, Autumn). New local meetup group: the Cork Vegans. The Irish Vegetarian, $133,20$.

Speedy, A. (2003). Global production and consumption of animal source foods. The Journal of Nutrition, 133 (11), 4048S-4053S.

Spence, L. (1999). The magic arts in Celtic Britain. Mineola, NY: Dover Publication, Inc.

Stack, L. (2015, November 4). Guinness is going vegan. The New York Times. Retrieved from: http://www.nytimes.com/2015/11/05/business/guinness-is-going-vegan.html

Teagasc Mushroom Stakeholder Consultative Group. (2013). Mushroom Sector Development Plan to 2020. Carlow: Agriculture and Food Development Authority.

The Irish Times. (1998, December 23). Grants awarded to animal groups. The Irish Times. Retrieved from: http://www.irishtimes.com/news/grants-awarded-to-animal-groups-

\section{$\underline{1.228295}$}

Tovey, H. (2006). New movement sin old places? The alternative food movement in rural Ireland. In L. Connolly and N. Hourigan (Eds.), Social movements and Ireland (168-189). New York: Manchester University Press.

Tovey, H. (1997). Food, environmentalism and rural sociology: on the organic farming movement in Ireland. Sociologia Ruralis, 37 (1), 21-37.

Tovey, H. (1991). "Of cabbages and kings": restructuring in the Irish food industry. The Economic and Social Review, 22 (4), 333-350.

Tovey, H. and P. Share. (2000). A sociology of Ireland. Dublin: Gill \& Macmillan Ltd. 
van Wijngaarden-Bakker, L. (1974). The animal remains from the Beaker settlement at Newgrange, Co. Meath: first report. Proceedings of the Royal Irish Academy. Section C: Archaeology, Celtic Studies, History, Linguistics, Literature, 74, 313-383.

Vegetarian Society of Ireland. (1978, October/November). Irish Vegetarian News, 1. Dublin: Vegetarian Society of Ireland.

Walsh, J. (2016, February 16). Cork wealthy dined on "turtle soup and champagne" during Ireland's Great Hunger. Irish Central. Retrieved from: http://www.irishcentral.com/roots/history/Cork-dined-on-turtle-soup-and-champagneduring-Irelands-Great-Hunger.html

Wiley, A. (2011). Re-imagining milk: cultural and biological perspectives. New York: Routledge.

Chaomhánach, E. (2002). The lore of the bee, its keeper and produce in Irish and other folk traditions. Dublin: University College Dublin.

Wells, R. (1994, April). Review: The largest amount of good: Quaker relief in Ireland, 16541921. Canadian Journal of History, 29, 208-211.

Wrenn, C. (2013). Nonhuman Animal rights, alternative food systems, and the non-profit industrial complex. Phaenex, 8 (2), 209-242.

Wrenn, C. (2016). Professionalization, factionalism, and social movement success: A case study on Nonhuman Animal rights mobilization. Dissertation. Forthcoming.

Yalden, D. (1999). The history of British mammals. London: Academic Press.

Yates, R. (2011). Criminalizing protests about animal abuse. Recent Irish experience in global context. Crime, Law and Social Change, 55, 469-482. 
Yates, R. (2013, April 5). Veganism is the new black: the growth of the vegan movement in Ireland. Indymedia Ireland. Retrieved from: http://www.indymedia.ie/article/103502

Yates, R. (2015, November 11). Tim Barford's VegFestUK helping to bring the vegan animal rights grassroots together and to the fore. On Human Relations with Other Sentient Beings. Retrieved from: http://onhumanrelationswithothersentientbeings.weebly.com/theblog/tim-barfords-vegfestuk-helping-to-bring-the-vegan-animal-rights-grassrootstogether-and-to-the-fore 